\title{
NOWE AGENDY SOCJALIZACJI KONSUMENCKIEJ W PROCESIE WYCHOWAWCZYM
}

\author{
Wiktoria Morawska \\ Instytut Socjologii, Instytut Historii Sztuki \\ Uniwersytet Wrocławski \\ Plac Uniwersytecki 1, 50-145 Wrocław \\ E-mail: wiktoria.morawskapp@gmail.com \\ ORCID ID: https://orcid.org/0000-0002-4043-5290
}

\begin{abstract}
Abstrakt
Teza. Celem artykułu jest wskazanie wpływu mega- i makropoziomu na kształtowanie się nowych agend socjalizacji konsumenckiej w procesie wychowawczym. Artykuł stanowi próbę omówienia tezy, że współcześnie proces wychowawczy związany jest nie tylko z przemianami wartości czy przemianami definiowania rodziny, ale też protestami mającymi miejsce $\mathrm{w}$ przemyśle motoryzacyjnym $\mathrm{w}$ latach $30 \mathrm{XX}$ wieku, alokacją produkcji, marketingiem, globalizacja, konsumpcjonizmem, rozwojem nowych mediów i transformacją ustrojową w Polsce.

Omówione koncepcje. Analiza łączy w sobie teorie dotyczące problematyki szeroko pojętej konsumpcji, w tym teorię społeczeństwa konsumentów Zygmunta Baumana (2009), brandingu narodu Jamesa McNeala (2006), koncepcje zmian społeczeństwa w XX i XXI wieku oraz globalizacji. Wyjściową teorią artykułu stały się tezy Beverlyego Silvera (2009).

Wyniki i wnioski. W opracowaniu wskazano, że we współczesnym społeczeństwie doszło do transformacji agend socjalizacji, czego przyczyną są przede wszystkim zmiany na mega- i makropoziomie. Ich skutkiem stało się utowarowienie jednostki. W opracowaniu zwraca się uwagę na problematykę „gry rynkowej” związanej z sukcesem i awansem społecznym rodziny, które mają być osiągnięte dzięki rozwojowi dziecka - „najdroższej inwestycji” (Bielecki, 2004).

Wartość poznawcza podejścia. Największą wartość stanowi oryginalna, dotychczas nie podejmowana perspektywa analizy procesu wychowawczego współczesnego dziecka nie tylko w kontekście rodziny, środowiska i konsumpcji, ale też procesów zmian w zarządzaniu przedsiębiorstwami i kadrą pracowniczą. Tak przyjęta perspektywa wynika z przekonania, że współczesna rzeczywistość wymaga nie tylko analizy psychologicznej z perspektywy jednostki czy socjologicznej analizy grupy i systemu edukacji, ale także problemów na poziomie międzynarodowym. Zainteresowanie tą problematyką wynika z przyjęcia tezy Samuela Huntingtona o konsolidowaniu się światowej gospodarki (Huntington, 2003).
\end{abstract}


Słowa kluczowe: wychowanie, konsumpcja, marketing dziecięcy, tożsamość, globalizacja, nowe media, współczesna rodzina, alokacja

\section{New agendas of consumer socialization in the educational process}

\section{Abstract}

Thesis. The aim of the article is to present the impact of mega- and macro-levels on the formation of new consumer socialization agendas in the educational process. The article is an attempt to explain the assumption that today the educational process is associated not only with changes in values or changes in defining the family, but also protests in the automotive industry in the 1930s, production allocation, marketing, globalization, consumerism, development of new media and the political transformation in Poland.

Concepts discussed. The analysis combines theories on the issues of broadly understood consumption, including the theory of the consumer society by Zygmunt Bauman (2009), or the branding of the nation by James McNeal, with several approaches to social changes and globalization in the 20th and 21st centuries, among which Beverly Silver's (2009) thesis was crucial.

Results and conclusions. The article draws attention to the issue of modification of the individual and the "market game" associated with the success and social promotion of a family mediated by child development - "the most expensive investment".

The cognitive value of the approach. The most important value is the original, not undertaken so far, perspective of analyzing the educational process of a modern child - not only in the context of family, environment and consumption, but also the processes of change in the work organization and staffing. The adopted imperative results from the belief that contemporary reality requires not only psychological analysis from the perspective of the individual or sociological analysis of the group and the education system, but also of the problems taking place at the international level, adopting Samuel Huntington's thesis on the consolidation of the world economy ((Huntington, 2003).

Key words: education, upbringing, consumption, children's marketing, identity, globalization, new media, modern family, allocation

\section{WPROWADZENIE}

Przedmiotem współczesnych badań nad rynkiem i gospodarką stają się najczęściej jednostki dorosłe: konsumpcyjnie aktywni uczestnicy systemu społecznego. Jednak zmiany zachodzące $\mathrm{w}$ ramach globalizacji, nowe trendy $\mathrm{w}$ obszarze planowania rodziny oraz postępująca indywidualizacja jednostek we wszystkich obszarach życia doprowadziły do segmentacji rynku i redefiniowania charakteru kapitalizmu, w ramach którego korporacje coraz agresywniej rywalizują o dziecięcych konsumentów (Barber, 2008) i przenoszenie ich potrzeb na dorosłych.

W dotychczasowych badaniach na ten temat najczęściej omawiane są konsumpcyjne konsekwencje globalizacji. Oprócz nich znaczący wpływ mają procesy transformacji systemowej w Polsce, które zwiększyły nie tylko możliwości alokacyjne, ale też 
aspiracje grup społecznych, które przed 1989 rokiem zaliczane były do klasy robotniczej. Przyczyniło się to do podwyższenia wieku, w którym pary decydują się na ślub lub dziecko czy zmiany statusu dziecka, jako „realizatora zadań” prowadzących do awansu i spełniania potencjału rodziny (Bogunia-Borowska, 2019). Według Joanny Malinowskiej celem rodziców stało się posiadanie dziecka „wysokiej jakości”, które wymaga od nich licznych inwestycji (Malinowska, 2019). Współczesne dziecko jest również „,specjalistą" do spraw konsumpcji i często przewodnikiem dorosłych po nowych branżach rynku czy rozrywki (Bogunia-Borowska, 2019).

Prywatyzacja i komercjalizacja większości obszarów życia generuje koszty zewnętrzne, transformując agendy socjalizacji w procesie wychowawczym, z którymi mierzą się nie tylko rodzice, ale też instytucje, szkoły, przedszkola i dzieci. Można stwierdzić, że socjalizacja dzieci stała się procesem jeszcze bardziej intensywnym niż kiedykolwiek. Implementacja do życia społecznego dokonując się jednocześnie, na wcześniejszym niż do tej pory etapie, na poziomie małych grup, instytucji i całego społeczeństwa.

Jednym z asumptów owych zmian w zakresie socjalizacji konsumenckiej są protesty organizowane głównie w przemyśle samochodowym od lat 30 XX wieku. Przyczyniły się one do rozpoczęcia działan - traktowanych jako rozwiązanie problemu kontroli siły roboczej i zatrzymanie strajków - m.in.: zwiększenia mobilności kapitału, alokacji produkcji do krajów pozbawionych podstaw ochrony pracowników i tych ze słabo rozwiniętymi związkami zawodowymi (Silver, 2009). Doprowadziło to do wykorzystywania taniej siły roboczej oraz zwiększenia automatyzacji produkcji. Efektem tych zjawisk są zmiany w organizacji gospodarki, które bezpośrednio wpłynęły na możliwości marketingowe organizacji. Środki zaoszczędzone poprzez wyzysk i stałe osłabienie strukturalnego potencjału pracowników (Sassen, 2007) w krajach peryferyjnych oraz wprowadzenie nowych strategii zarządzania, umożliwiły wzmacnianie marketingowego konsumpcjonizmu w krajach centralnych. Co więcej, jak sugeruje Klaus-Jurgen Tillman, od roku 1960 zmieniła się codzienna sytuacja życiowa dzieci i młodzieży, co związane było ze zmniejszająca się kontrolą rodzicielską (Tillman, 2005). Od wczesnych lat 70, wraz z powstaniem marketingu społecznego w krajach wysoko rozwiniętych, zaszły zmiany w pojmowaniu samego marketingu. Zwiększyło się znaczenie zgodności pomiędzy potrzebami konsumenta jako jednostki, jak i ogółu społeczeństwa (Bogunia-Borowska, 2004).

\section{KONSEKWENCJE PRZEMIAN - NOWE AGENDY SOCJALIZACJI KONSUMENCKIEJ}

W efekcie przemian na mega- i makropoziomie organizacje, już na początku XXI w., wykreowały nowego, nieświadomego, ale niezwykle istotnego konsumpcyjnego "gracza": dziecko. Dzieci, uwikłane w rynkowy kontekst, poddawane są procesowi socjalizacji konsumenckiej już, na co wskazuje Center for a New American Dream (Centrum dla Nowego Amerykańskiego Snu) w wieku półtora roku, kiedy to są w stanie wyobrażać sobie logo, czy symbole konkretnych, popularnych marek (Media Smarts). Dla rynku stają się jednak najważniejsze w wieku czterech lat, czyli w okresie tzw. wczesnego dzieciństwa (Tillman, 2005), kiedy to zdobywają umiejętność wyartykułowania swoich preferencji (Barber, 2008).

Ogrody Nauk i Sztuk nR 2020 (10) 
Co więcej - są permanentnie odbiorcami mimo woli, bo w przeciwieństwie do rodziców, którzy zostają postawieni w takiej sytuacji raz na jakiś czas - na przykład podczas wyświetlania trzyminutowych reklam podczas musicalu Stomp w nowojorskim Orpheum Theater (Barber, 2008) - dzieci nie mają żadnego głosu decyzyjnego.

Z jednej strony nie posiadają jeszcze narzędzi do świadomego oddzielania reklam od sztuki, czy rzeczywistości społecznej, co według Wilhelma Heitmeyera związane jest $\mathrm{z}$ erozją umiejętności autonomicznego działania $\mathrm{w}$ ramach procesów indywidualizacji (Tillman, 2005). Z drugiej strony: mimo woli poddawani są stałym bodźcom marketingowym. Badania przeprowadzone przez Kaiser Family Foundation, którym objęto amerykańskie dzieci w 2005 roku wykazały, że przeciętnie młodzi ludzie mają bezpośredni kontakt $\mathrm{z}$ treściami nadawanymi przez media przez 8 i pół godziny dziennie (Barber, 2008).

Ważne jest to również dlatego, że dzieci inaczej niż dorośli odbierają reklamy, co wykazały m.in. badania przeprowadzone przez MediamarkResarch Inc. Według raportu prawie $60 \%$ z 5400 dzieci w wieku od 6 do 11 lat nie ignoruje reklam i ogląda je z równym zainteresowaniem, co konkretne programy telewizyjne (Ives, 2005). Badania psychologów takich, jak Robert Baker, wykazały, że dzieci do piątego roku życia szukają modelowych postaci, na podstawie których tworzą tożsamość rodzajową. W tym okresie wytwarzają się upłciowione preferencje w stosunku do zabawek, książek, czy ludzi (Hoły-Łuczaj, Łuczaj, 2019). Kwestie te zostały co prawda zauważone i uwzględnione w powstałym w 2014 roku Kodeksie Etyki Reklamy, jednak zakres stosowalności tego dokumentu nie został do tej pory zbadany. Tym samym nie sa prowadzone reprezentatywne badania wykazujące wpływ kodeksów etycznych na projektowanie reklam.

Zjawiska te stanowią jeden ze wskaźników globalizacji, kiedy aktorzy gospodarki dążą do ujednolicenia preferencji, jak i decyzji swoich odbiorców. Uzyskanie skonsolidowanych potrzeb jest najłatwiejsze w przypadku standaryzowanej komunikacji marketingowej z dziećmi. Według Jamesa McNeala ma to związek z faktem, że kultura dziecięca ma symboliczne „pierwszeństwo” nad kulturą danego obszaru geograficznego (McNeal, 2006). Wynika to ze wspólnych cech dzieci: emocjonalności, koncentracji zainteresowań na zabawie, potrzeby bezpieczeństwa.

Fakt podwyższania się poziomu życia w krajach centralnych i semi-peryferyjnych prowadzi do wdrażania nowego typu obowiązków (a według niektórych nawet braku obowiązków), które nakładane są na dzieci. Rzadko kiedy wykonują one prace o prostym charakterze fizycznym, jakie wykonywały dzieci, szczególnie wiejskie, jeszcze kilkadziesiąt lat temu. W zamian wychowywane są w rzeczywistości nieustannego generowania pragnień i lęku przed pełnym zadowoleniem $i$,"nasyceniem" (Bauman, 2009), które to staje się wspólnym polem, na którym funkcjonują „zbliżone do siebie": dzieci i dorośli zinfantylizowanej rzeczywistości (Bogunia-Borowska, 2019).

Towarzyszy temu ujednolicenie preferencji prowadzące do powstania opisanego przez Zygmunta Baumana społeczeństwa konsumentów, gdzie społeczeństwo „interpeluje” swoich członków, tzw. homo eligens, w tym dzieci, oceniając i sankcjonując (Bauman, 2009). Bauman pisze: „społeczeństwo konsumentów posługuje się narzędziami tresury i przymusu dla zarządzania duchem - pozostawiając zarzą- 
dzanie ciałem indywidualnie podejmowanym staraniom, nadzorowanym i koordynowanym przez wymusztrowaną już jednostkę" (Bauman, 2009, s. 63). Oznacza to, że we współczesnym społeczeństwie skuteczność (doskonałość lub jej brak) działań konsumenckich staje się najważniejszym czynnikiem uwarstwienia społecznego, tym samym mogąc prowadzić do wykluczenia lub akceptacji danej jednostki we wspólnocie, ale też w szeroko pojętej opinii publicznej. Juliet Schor opisuje to słowami: „przywiązujemy mniejszą wagę do uczenia swoich dzieci rozwoju społecznego, intelektualnego, nawet duchowego, niż do wytrenowania ich na konsumentów" (Schor, 2005, 13).

Zjawisko to dotyczy też dzieci, które zdają się jeszcze silniej ulokowane w konsumpcyjnej rzeczywistości niż współcześni dorośli. Poprzez przemiany technologiczne i reorganizację metod edukacji, dzieci są stale poddawane „konsumpcyjnym bodźcom" a szkoła, którą Talcott Parsons w XX wieku nazywał stabilizatorem systemu społecznego (Tillman, 2005), zaczyna odgrywać coraz mniejszą rolę. Przeniesienie nauki z bibliotek czy książek w domu na laptopy, daje możliwość wysyłania do odbiorcy stałego sygnału reklamowego oraz permanentnego jego zainteresowania i podjudzania. Co więcej, sami rodzice wprowadzani są w przekonanie, iż konsumpcja i zapewnianie dzieciom odpowiednich zabawek, programów i materiałów stanie się gwarancją ich przyszłego sukcesu. Zjawisko to Mateusz Halawa określa mianem kosztorysowania rodzicielstwa (Halawa, 2006), a Jędrzej Bielecki w artykule dla dziennika "Rzeczpospolita” nazywa dziecko, "po prostu”, "najdroższą inwestycją" (Bielecki, 2004).

Ów sukces dziecka stał się szczególnie ważny dla rodzącej się klasy średniej posttransformacyjnej Polski (Bogunia-Borowska, 2019). Można powiedzieć, że rodzice praktycznie realizują hasło reklamowe konsoli The V. Smile przekonani, że ,jeśli nie grasz w gry wideo, nie dostaniesz się do college'u” (Barber, 2008, s. 361), „podstawiając" pod gry każdy inny produkt, który akurat jest popularny na rynku i traktując rodzicielstwo w kategoriach rynkowej inwestycji.

Oznacza to, że dzieci często wychowywane są nie w poczuciu demokracji, obywatelskości a poczuciu wolności decyzji, gdzie nawet instytucje narodowe, czy cały naród staje się marką podlegającą brandingowi (McNeal, 2006), zaś wiedza i wzorce w dużej części czerpane są z medialnej encyklopedii wspótczesności (Bogunia-Borowska, 2004, s. 47). Aleksandra Kamińska zwraca również uwagę na zmiany w pojmowaniu celu rodziny, która w coraz mniejszym stopniu postrzega swoją rolę jako źródło wartości społecznych, czy historycznych, a same dzieci „wykorzeniają się”: usamodzielniają i rozwijają poza kręgiem najbliższych krewnych (Malinowska, 2019).

Z brandingiem narodu wiążą się również zmiany w dążeniach jednostek, których priorytetem staje się byciem modnymi, popularnymi i szanowanymi. Pośrednikiem do osiagnięcia tego celu staje się przynależność do konkretnego, cenionego towarzystwa, które to, szczególnie w ostatnich latach ma związek ze zjawiskami takimi jak: budowanie marki osobistej za pomocą nowych mediów, czy Influence Marketing. Narzędzia takie, jak Facebook, Instagram, czy YouTube stają się coraz bardziej popularne wśród małych dzieci. Wskazują na to choćby badania firmy analitycznej Deloitte, która wykazała, iż 95\% osób urodzonych po 2000 roku (Pokolenie Z) w Polsce ma dostęp do smartfona (Raport „Deloitte TMT Predictions”, 2016). 
Portale nowych mediów budzą zainteresowanie wśród coraz młodszych odbiorców zarówno ze względu na poszukiwanie wzorców i idoli, jak i rozpoczynanie budowania wizerunku dziecka na bardzo wczesnym etapie.

Przykładem zjawiska zwiększania popytu i „,wartości rynkowej” jednostki, w tym przypadku dziecka, może stać się profil Anny Pavagi - dziesięcioletniej dziewczynki-modelki, która zaczęła swoją karierę w wieku 3 lat. Aktualnie na Instagramie obserwuje ją 519000 osób (stan na wrzesień 2019 r.), zaś na jej koncie znajdziemy zarówno zdjęcia z kampanii komercyjnych, jak i filmiki tańczącej Anny, czy zdjęcia z masażu i placu zabaw. Pomimo że aktualnie nie ma rzetelnych danych na temat liczby dzieci zakładających i aktywnie prowadzących konta publiczne na portalach takich, jak YouTube czy Instagram, jednak ich skala podczas prostego ich przeglądania zdaje się być duża, szczególnie biorąc pod uwagę np. falę publikacji filmów około roku 2010 dotyczących gry Minecraft (Bogunia-Borowska, 2019).

\section{Podsumowanie}

W związku z nowymi mediami i rozwojem Internetu wielu teoretyków zwraca uwagę, iż współczesność zdegradowała trwanie na rzecz chwilowości i przemijalności odrzucając wszelką zwłokę. Tyczy się to zarówno trendów np. modowych, jak i chwilowości popularności konkretnych jednostek, szczególnie tych, których sława budowana jest za pomocą nowych mediów. Może to zjawisko tyczy się również obniżania wieku rozpoczynania kariery medialnej niczym u Anny Pavagi?

Jak pisze Z. Bauman „dojrzali konsumenci nie mają zahamowań wobec pozbywania się rzeczy (...) adepci sztuki konsumowania wiedza, że pozbywanie się rzeczy, których termin użyteczności (tj. dostarczania przyjemności) minął, jest wydarzeniem, z którego należy się cieszyć" (Bauman, 2009, s. 95). Zjawisko to wdrażane jest w ramach praktyk takich, jak firmy Mattel, która w 1996 roku zaproponowała młodym konsumentom, że jeśli zwrócą obecnie używana, „starą" lalkę Barbie dostaną nową za mniejszą cenę (Bauman, 2009).

Co więcej, współcześnie owymi „dojrzałymi konsumentami” stają się niedojrzałe jeszcze dzieci, które nie tylko uczestniczą w rynku nabywczym, ale często bardziej za nim „nadążają" niż ich rodzice czy dziadkowie.

Jak zwraca uwagę Maja Brzozowska-Brywczyńska, często mówiąc o zmianie statusu dziecka czy nowych aspektach procesów wychowawczych, przyjmuje się perspektywę krytyczna, traktującą dzieci jako ofiary konsumpcjonizmu lub aprobująca, w której dziecko staje się beneficjentem korzystającym $\mathrm{z}$ dóbr współczesności (Bogunia-Borowska, 2019). Z pełną świadomością nie chcę opowiadać się za żadną $\mathrm{z}$ tych perspektyw, jednak niewątpliwie w XXI wieku doszło do znaczących zmian $\mathrm{w}$ agendach socjalizacji konsumenckiej w procesie wychowawczym. Zdaje się jednak, że należy zwrócić uwagę, iż zmiany w wychowaniu dzieci wiążą się z procesami nie tylko na poziomie rodziny czy szkoły, ale zjawiskami mega- i makropoziomu, które prowadza, jak to określa Prerna Kohli, do „destandaryzacji” w prywatnym obszarze partnerstwa i rodzicielstwa (Tillman, 2005). Tym samym współczesna rzeczywistość wymaga nie tylko analizy psychologicznej z perspektywy jednostki czy socjologicznej analizy grupy i systemu edukacji, ale także problemów na poziomie światowej gospo- 
darki. Do tej pory oczywiste normy zostały zdominowane przez nowe zasady i nowe ryzyko, które współczesny rynek wykorzystuje tworząc nową "klasę" dziecięcych konsumentów i - metaforycznie - wychowując je przez konsumpcję.

\section{WSKAZANIA PEDAGOGICZNE - WNIOSKI}

Opisanym przeze mnie procesom towarzyszy zestaw wskazań pedagogicznych kierowanych przede wszystkim do rodziców i nauczycieli. Zalecenia te mają różne źródła. Publikowane są przez badaczy związanych z Ośrodkiem Rozwoju Edukacji, organizacjami edukacyjnymi, ale też przez psychologów, socjologów, pisarzy, filozofów czy samych nauczycieli. Wskazania przybierają różne formy, dotyczą komunikacji, kształtowania wartości i postaw, zdobywania samodzielności, czy wiedzy. Często skoncentrowane są na obszarach uwzględnionych w modelu czterech aspektów wychowania: wspomaganiu, korygowaniu, zapobieganiu i kształtowaniu (Garstka, 2015, s. 7). Tym samym wytyczne odnoszą się przede wszystkim do mikrostruktur społecznych, będąc nieodłącznie związane z dyscyplinami nauki takimi jak psychologia i pedagogika.

Wskazania o wyżej opisanym charakterze mają nieodzowne znaczenie i nie powinny być pomijane. Celem niniejszego artykułu jest jednak opisanie potrzeby uwzględniania $\mathrm{w}$ procesie wychowawczym problemów na mega- i makropoziomie. Wynika to z przekonania, że współczesna rzeczywistość, a przede wszystkim nowe agendy socjalizacji konsumenckiej wymagają od badaczy, rodziców i rządu przyjęcia nowej perspektywy. Oznacza to potrzebę nasilenia obserwacji, w ramach kontroli działalności reklamowej, przestrzegania Kodeksu Etyki Reklamy (Kodeks Etyki Reklamy, 2014).

Ważną kwestią są programy edukacyjne, w ramach których nie powinno się tylko dążyć do kształtowania postaw i wartości dzieci, ale też nauczać podstaw ekonomii, zarządzania finansami, czy podejmowania decyzji konsumenckich.

Jednocześnie powinno się to wiązać $\mathrm{z}$ wdrażaniem programów na rzecz zwalczania nierówności społecznych, które współcześnie wynikają przed wszystkim z jakości konsumpcji, nie zaś, jak do tej pory, z podziałów klasowych. Tym samym ochroną przed manipulacją $\mathrm{w}$ obrębie reklamy i programami edukacyjnymi powinno się obejmować nie tylko dzieci, ale przede wszystkim ich opiekunów.

\section{Bibliografia}

[1] Barber, R. B. (2008). Skonsumowani. Jak rynek psuje dzieci, infantylizuje dorostych i połyka obywateli. Warszawa: Warszawskie Wydawnictwo Literackie MUZA SA.

[2] Bauman, Z. (2009). Konsumowanie życia. Kraków: Wydawnictwo Uniwersytetu Jagiellońskiego.

[3] Bogunia-Borowska, M. (2004). Reklama jako tworzenie rzeczywistości społecznej. Kraków: Wydawnictwo Uniwersytetu Jagiellońskiego.

[4] Bogunia-Borowska, M. (2006). Dziecko w świecie mediów i konsumpcji. Kraków: Wydawnictwo Uniwersytetu Jagiellońskiego.

[5] Bogunia-Borowska, M. (2019). Wspótczesny świat dziecka. Media i konsumpcja. Kraków: Wydawnictwo Uniwersytetu Jagiellońskiego.

[6] Bogunia-Borowska, M. (2019). Słodkie potwory i powroty do przeszłości albo kilka notatek na marginesach dwóch estetyk dzieciństwa. W: M. Bogunia-Borowska (red.), Wspótczesny świat dziecka. Media i konsumpcja (ss. 77-102). Kraków: Wydawnictwo Uniwersytetu Jagiellońskiego. 
[7] “Deloitte TMT Predictions 2016 r." Pobrane z : https://www2.deloitte.com/pl/pl/pages/press-releases/articles/TMT-konsument-przyszlosci-patrzy-na-swiat-przez-urzadzenia-mobilne.html [dostęp: 25.09.2019 r.].

[8] Garstka, T. (2015). Model czterech aspektów wychowania w praktyce. Jak go wykorzystać przy tworzeniu programu wychowawczego? Pobrane $\mathrm{z}$ : http://bc.ore.edu.pl/dlibra/docmetadata?id=752\&from=pubindex\&dirids=1\& lp=384 [dostęp: 03.04.2020 r.].

[9] Halawa, M. (2019). Komercjalizacja dzieciństwa. Kosztorysowanie rodzicielstwa. W: M. Bogunia-Borowska (red), Wspótczesny świat dziecka. Media i konsumpcja (ss. 44-76). Kraków: Wydawnictwo Uniwersytetu Jagiellońskiego.

[10] Hoły-Łuczaj, M., Łuczaj, K. (2019). Nowe bohaterki medialnej rzeczywistości filmów dla dzieci. W: M. Bogunia-Borowska (red.), Współczesny świat dziecka. Media i konsumpcja (ss. 161-178). Kraków: Wydawnictwo Uniwersytetu Jagiellońskiego.

[11] Ives, N. (21.11.2005). No skipping: ChildrenStill Watch TV Ads [Bez pomijania: dzieci wciąż oglądają reklamy telewizyjne]. Pobrane z: www.Media-Works.com, [dostęp: 03.10.2019 r.].

[12] Malinowska, J. (2019). Współczesny obraz rodzicielstwa i dzieciństwa w zwierciadle popkultury. W: M .Bogunia-Borowska (red.), Wspótczesny świat dziecka. Media i konsumpcja (ss. 119-130). Kraków: Wydawnictwo Uniwersytetu Jagiellońskiego.

[13] McNeal, J. U. (2006). Kids as customers: a handbook of marketing to children [Dzieci jako konsumenci: podręcznik marketingu dziecięcego]. Lanham: Rowman and Littlefield.

[14] Media Smarts. Pobrane z: http://mediasmarts.ca/digital-media-literacy/media-issues/marketing-consumerism/how-marketers-target-kids [dostęp: 30.08.2019 r.]

[15] Sassen, S. (2007). Globalizacja. Eseje o nowej mobilności ludzi i pieniędzy. Kraków: Wydawnictwo Uniwersytetu Jagiellońskiego.

[16] Schor, J. (2005). Born to Buy [Urodzeni do zakupów]. New York: Charles Scribner's Sons.

[17] Silver, B. J. (2009). Globalny proletariat. Ruchy pracownicze i globalizacja po 1870 r. Warszawa: Instytut Wydawniczy Książka i Prasa.

[18] Tillmann, K. J. (2005). Teorie socjalizacji. Społeczność, instytucja, upodmiotowienie. Warszawa: Wydawnictwo Naukowe PWN. 